\title{
Assessing the Impact of E-Procurement on the Performance of Public Sector Organizations: Evidence from Nigeria
}

\author{
Hauwa Wuraola Aliyu Umar Abbas Ibrahim, PhD \\ Department of Business Administration, Nile University of Nigeria, Abuja
}

\begin{abstract}
Electronic procurement is one of the emerging trends in procurement process especially in developing countries, and it represents an important achievement for organizations striving to triumph in health competitiveness. This study aims to assess the impact of e-procurement on the performance of public sector organizations in Nigeria. Data were obtained from sample of 50 involved employees from INEC, TETFUND and NBS that represents critical public organisations in Abuja through open-ended questionnaire. Using inferential and regression instrument of analysis, the findings suggest that e-procurement exerts a significant and positive impact on performance of Public Sector Organizations in Abuja, Nigeria. Other variables adopted are technological infrastructure, organization size and top management attitude. It also revealed that MDAs have adopted Eprocurement process in procurement activities. The study recommends for Government to continue to provide an enabling environment in terms of information technology Infrastructure and leadership to improve the procurement process. The study also reiterates the need for further research on the institutional responses to Eprocurement adoption in Public Sector Organizations in Nigeria.
\end{abstract}

Keywords: Electronic procurement, supply chain management, technological infrastructure,organization size, top management attitude, performance.

${ }^{1}$ ORCID- 0000-0002-5076-3204; ${ }^{2} \mathrm{CRCID} / 0000-0001-8273-9148$

DOI: $10.7176 / \mathrm{EJBM} / 13-13-04$

Publication date:July $31^{\text {st }} 2021$

\subsection{Introduction}

Procurement system is a vital part of an organization's supply chain system. Effective and Efficient use of goods, works and services starts with getting them at the most realistic and cost effective way and without that profits cannot be made. Any organization that strives for excellence must find a way of procuring wisely. The importance of procurement in an organization cannot be over-emphasized. Public sector organization of any economy plays a great part in the success of any nation. Procurement, which is the process of obtaining goods and services mainly for business purposes, is a core function of any organization.Information Technology in the past few decades has changed the way in which organizations communicate, conduct business, and interact with one another and government agencies. There has been a revolution in technological progress which has benefited the business world and has allowed organizations to work more efficiently and maximize productivity.

To make E-procurement work in an organization an E-procurement software must be set-up. With this you eliminate the need for paper based methods and through automation you no longer requireprocesses that are time-consuming and and likely to have error prone ways of doing things. Globally E-procurement is more known with the invention of technology. Electronic procurementis the act of using electronic methodsmainly the internet and solutions mainly in cloud but also hardware created software applications, to achieve and enhance the sourcing and buying of goods and services through internet, processing and information dissemination

AWorld Bank analysis showed that UMUCYO is a web based E-procurement system introduced in Rwanda based on a law passed in 2007 (Gihozo, 2020). Many other Countries including Nigeria was one of the early beginners of E-procurement in Africa especially the Building industry Nigeria (Adeniyi et al., 2020). Some Multi national organisations like NLNG had also started the use of E-procurement but the Procurement law that supported E-procurement was signed into law in 2007 (Shatta et al., 2020). The introduction of the law came about following a survey of assessment carried out by world bank conducted in 1999 which established the nexim between poor/frail public procurement procedure and corruption and the report said 60k was being lost from every One Naira spent by Government due to sharp and underhand practices (Akaba et al., 2020). An average of ten billion dollars was lost annually due to fraud in award and execution of Government contracts and it is against this scenery that this study seeks to examine the impact of E-procurement on performance of public sector organizations based on the opinions of staff of public sector organizations in Abuja, Nigeria (Akaba et al., 2020).

E-procurement has been identified as a major tool to drive transparency, accountability and responsibility in any great economy. Traditionally procurement involves huge paper work as well as integration of sellers relationship through transparent processes in procurement methods (carayannis and popescu, 2005). Eprocurement can have a great impact in making the procurement to be more simple and very efficient. Eprocurement technological application leads to greater profitability and greater cost savings for businesses. Use 
of E-procurement helps to reduce cost of procurement and also provides a plan for better co-ordination between suppliers,better transaction process time and better methods(Samaniego et al. 2006)

Failing to prepare is preparing to do what is absolutely not beneficial to an organization. Preparing involves getting raw materials, sourcing for manpower and using the best possible means to carry out operations. The only way to succeed as a company is to procure wisely. If there is an error in procurement then the whole process of running a business is flawed. Procuring electronically is a dependable way to be sure that you have prepared properly. E-procurement has been identified as a major tool to drive transparency, accountability and responsibility in any great economy. Traditionally procurement involves huge paper work as well as combination of suppliers relationship through transparency in procurement process . E-procurement can have a major impact in making the procuring simpler and better. E-procurement technological application leads to increase profit and better cost savings for Organizations. Use of E-procurement helps to reduce cost of purchasing and also provides a basis for good co-ordination between different suppliers, faster transaction time and better and improved process efficiency.

The Objective of this research is to find out how public sector organizations are adopting e-procurement in Nigeria and how e-procurement has improved the performance of public sector organization in Nigeria and to determine the level of use of e-procurement in the operations of Ministries, Departments and Agencies either to a degree or full use of E-procurement in public Organizations in Nigeria. There have been researches carried out on the effect of E-procurement in Nigeria as related to Corruption (Aduwo et al., 2020), and also effect on the performance in Construction (Ibem et al., 2020). This study seeks to address this vital gap by checking the staff of Public sector organizations in Abuja, Nigeria in order to find out the level to which E-procurement affects the success and performance of Organizations in public sector in Abuja, Nigeria'

\subsection{Objectives of the study}

I To provide an insight on the perceived improvement in performance of public sector institutions by adopting Eprocurement.

ii To find the nature of relationship between public sector organizations and technological infrastructure

iii To find the effect of organization size on the performance of public sector organizations

iv To find the multiplying effect of top management attitude on the performance of public sector organizations.

\subsection{Research Questions}

The following research questions were raised and answered:

i. What are the perceived improvement in performance of Public Institutions by adopting Eprocurement?

ii. What is the nature of relationship between Public Sector Organisations and Technological Infrastructure?

iii. What is the effect of organization size on performance of public sector organization ?

iv. What are the multiplying effects of Top management attitude on the Performance of Public Sector Organizations in Nigeria?

\subsection{Research Hypothesis}

i.HO1: E-procurement does not have any significant impact on the performance of Public Sector Organizations.

ii. $\quad \mathbf{H O}_{2}$ : Technological Infrastructure does not have any relationship with performance of Public Sector Organizations.

iii. HO: Organization size does not have any effect on performance of Public Sector Organizations.

iv. $\quad \mathbf{H O}_{3}$ : Top management attitude does not have any multiplying effect on the performance of Public Sector Organizations.

\section{Literature Review}

2.1 E-procurement which is the use of information technology to creat a procurement process that gears to respond to difference in the environment is adopted by all industries and various kinds of organizations. The greatest use of E-procurement comes to the fore when it's application is completely integrated throughout the supply chain.

Technological Infrastructure which is a set of information technology components that can be seen or not that is the hardware and software facilities of an organization is a critical tool in improving the performance of any organization.

Organizational size which is the number of employees at any given geographical location which is the manpower strength of an organisation is a vital tool in strategic management that helps in making a successful 
organization.

Any organization is a reflection of its top management attitude. Top management attitude is the way or behaviour of the group of people who are responsible for establishing policies, guidelines and strategic objectives as well as providing leadership in an organization. Whatever they decide determines the success or not of an organization vis a vis its performance.

E-procurement implementation success in the Public Sector is usually influenced by some critical factors. Despite government efforts through reforms for easy adoption of E-procurement, adopting it still remains a big challenge. Findings of research done by Cooper and Schindley (2003) on E-procurement revealed that Eprocurement encourageskeeping recordson all the process in bidding which in turn enhances improved transparency in processes and good accounting in public procurement organizations. The research further showed that E-procurement is tallied with better efficiency and enhanced purchasingprocesses.

E-procurement plan refer to the different models used to manage internet supply chain processes in an organization (Roman, 2013) . There are various softwares or online processes used to make organizations work better and to facilitate wise E-procurement practices. There are various e-procurement packages used all around the world.

Harelimana(2018) found out that E-procurement models leads to better restitution of customer demand, Improved purchase and supply compliance, improved purchasing capacity, reduced cost of inventory and better efficiency inventory management. The group showed the keys to E-procurement process cyclesuccess. They pointed out that E-procurement should not be seen as a strategy but a full plan. The organization must know what it spends on, the Organization must have a total E-procurement plan, the application of E-procurement begins by agreeing on theprocess and use of E-procurement must be led from up to bottom. The application of E-procurement must be decided by all and supported by other functional areas.

\subsection{Theoretical Framework}

Diffusion of innovation theory is the theory adopted by the study. It was postulated in 1962 by an American Economist called Everett Rogers. Diffusion of innovation theory is widely used in the area of technology spread and use. For Rogers "a technology is a design for involved action that reduces the unknown in the cause consequences relationship involved in achieving a wanted outcomeSpread of new methods" (Sherry \& Gibson, 2002) . For Rogers (2003) adoption is a decision of complete use of an innovation as the best way of action availableand refusal is a decision not to adopt an innovation. As expressed in this diffusion of innovation. Diffusion is seen as communicating a new course of action to people over a period of time. It involves weighing the advantages or disadvantages of taking a course of action. It postulates that there are different stages of innovation decision processes and they are knowledge, persuasion, decision, implementation and confirmation. And there are innovators, early adopters, early majority, late majority and laggards. The criticism of the study is that the technical factor is not the only factor to be considered in the spread of innovation. Other factors like economic , social, political and the general environment are important and are to be considered.

\subsection{Empirical Review}

Apart from process and cost as discussed by Matunga et al. (2013) lack of change in top management and enough training of staff makes adoption of E-procurement an herculean task. Other challenges have been epileptic network connection or unreliableinternetavailability in some areas and limited number of government agencies with ICT infrastructure and connectivity. Consequently organizations tend to selectively take up the use of E-procurement processes thus limiting its effect on overall Organizations performance.

A study was also done which revealed that sellers play a vital role in determining if organizations take part or notin E-procurement system. The attitude and ability of the supplier defines whether they participate in Eprocurement methods,processes or not. In the case of organizations, the new way of doing things in a transparent way and integrity required by the E-procurement system make old suppliers reluctant because they are set in their ways so they areagainst it. This is because the E-procurement processesdisrupts the old relationship between procuring body and sellers.

\section{Methodology.}

\subsection{Sources of Data and Methods of Analysis:}

The research design used in this study is descriptive cross sectional survey method aimed at establishing the effect of E-procurement on performance in public sector organizations in Nigeria.

Fifty (50) structured questionnaires were administered to staff of INEC, TETFUND and NBS spread across various departments of the Public Organizations all based in Abuja. This comprises of 44\%(22 respondents) from INEC, 18\% (9 respondents) from TETFUND and 38\% (19 respondents) from NBS respectively. For successful investigation, this research work is based on descriptive statistics technique using frequency approach. The format of the Questionnaire is Likertscale which is a unidimensional scale used by researchers to collect 
respondents' attitudes and opinion.The data analysis method adopted is the frequency analysis of Statistical package for the social sciences(SPSS), regression analysis which is a set of statistical processes for estimating the relationships between a dependent variable and one or more independent variables and Anova. Frequency analysis is a descriptive statistical method that expresses the number of times that an incident occurs of each response chosen by respondents.Anova is a statistical method in which the variation in a set of observations is divided into distinct components. The data used for the study is primary data and this is to show the relationship between the variables which is performance and E-procurement and frequency analysis was used to determine the relationship and impact of E-procurement on Performance in Public Organization using three MDAs in Abuja ( INEC, TETFUND and NBS).

\section{Analysis of Data and interpretation of results.}

This section deals with presentation and analysis of the data. Data was analysed by coding and frequency analysis, regression analysis and anova was used to determine results aiming at providing answers to the research questions and testing the set hypotheses.

\subsection{Data Presentation, Analysis and Findings.}

\section{Background characteristics of respondent}

Respondents cut across various departments with varying grade levels and years of experience. $8 \%$ of them are from grade level 13 and above while majority (78\%) are between grade level $8-12$. Further, $38 \%$ of the respondents have spent between $0-5$ years in service, $44 \%$ are between $6-10$ years, $4 \%$ range $11-15$ years, $6 \%$ are (16-20) years and 4\% have spent 20 years and above. Of all the respondents, $24 \%$ are from procurement department, $12 \%$ are from Admin and Human Capital, $8 \%$ from ICT while 34\% are from other departments in their various organisations. The distribution was also not gender blind, $60 \%$ of our respondents were male while $40 \%$ were female. Educational qualification of respondents cuts across first and higher degrees; $64 \%$ of the respondents possess first degree or advanced diploma while 17\% have master's degree and all respondents are from Public Organization.

Table 4.1Which Organization do you work for?

\begin{tabular}{|ll|l|l|l|l|}
\hline & & & Valid & \\
Percentage & Cumulative Percentage \\
\hline Valid & INEC & 22 & Percentage & 44.0 & 44.0 \\
& TETFUND & 9 & 44.0 & 18.0 & 62.0 \\
& NBS & 19 & 38.0 & 38.0 & 100.0 \\
Total & 50 & 100.0 & 100.0 & \\
\hline
\end{tabular}

The table above shows the amount of respondents from each organization surveyed.the percentage of respondent fron INEC, TETFUND and NBS.

Table 4.1 above shows the distribution of respondents across three organizations for the study, they are; Independent National Electoral Commission (INEC), Tertiary Fund (TETFUND) and National Bureau of Statistics (NBS). As indicated, 44\% of our respondents are from INEC, 38\% from NBS while the remaining $18 \%$ are from TETFUND.

Table 4.2 What position do you hold in your Organization?

\begin{tabular}{|c|c|c|c|c|c|}
\hline & & Frequency & Percentage & $\begin{array}{l}\text { Valid } \\
\text { Percentage }\end{array}$ & $\begin{array}{l}\text { Cumulative } \\
\text { Percentage }\end{array}$ \\
\hline \multirow[t]{4}{*}{ Valid } & & 7 & 14.0 & 14.0 & 14.0 \\
\hline & Grd level 13 and above & 4 & 8.0 & 8.0 & 22.0 \\
\hline & Grd level 8 to 12 & 39 & 78.0 & 78.0 & 100.0 \\
\hline & Total & 50 & 100.0 & 100.0 & \\
\hline
\end{tabular}

The table above showed the spread of grade level of respondents in the organizations surveyed.

From table $4.2,78 \%$ of the respondents are from grade level $8-12$, while only $8 \%$ are from grade level 13 and above. 
Table 4.3 For how long have you worked in your Organization?

\begin{tabular}{|ll|l|l|l|l|}
\hline & Frequency & Percentage & $\begin{array}{l}\text { Valid } \\
\text { Percentage }\end{array}$ & $\begin{array}{l}\text { Cumulative } \\
\text { Percentage }\end{array}$ \\
\hline Valid & $0-5$ & 19 & 38.0 & 39.6 & 39.6 \\
& $6-10$ & 22 & 44.0 & 45.8 & 85.4 \\
& $11-15$ & 2 & 4.0 & 4.2 & 89.6 \\
& $16-20$ & 3 & 6.0 & 6.3 & 95.8 \\
& 20 and above & 2 & 4.0 & 4.2 & 100.0 \\
Missing & Total & 48 & 96.0 & 100.0 & \\
Total & System & 2 & 4.0 & & \\
\hline
\end{tabular}

The table above displayed the amount of years each respondent has spent working in their various organizations.

Table 4.3 shows the length of period that the respondents have worked in their respective organizations, $44 \%$ of them have spent between $6-10 y$ rs followed by officers that have spent less than 5 years, this category constitute $38 \%$. There are only few people (4\%) that have spent 20years and above.

Table 4.4 What unit/department do you workin?

\begin{tabular}{|ll|l|l|l|l|}
\hline & Frequency & Percentage & $\begin{array}{l}\text { Valid } \\
\text { Percentage }\end{array}$ & $\begin{array}{l}\text { Cumulative } \\
\text { Percentage }\end{array}$ \\
\hline Valid & & 9 & 18.0 & 18.0 & 18.0 \\
& Administration \& Human & 6 & 12.0 & 12.0 & 30.0 \\
capital department & 4 & 8.0 & 8.0 & 38.0 \\
ICT & 12 & 24.0 & 24.0 & 62.0 \\
Procurement and supply & 1 & 2.0 & 2.0 & 64.0 \\
Legal dept & 1 & 2.0 & 2.0 & 66.0 \\
Finance and account & 17 & 34.0 & 34.0 & 100.0 \\
OTHERS & 50 & 100.0 & 100.0 & \\
Total & $24 \%$ & & \\
\hline
\end{tabular}

From table 4.4 above, it shows that $24 \%$ of the respondents are from Procurement department, $12 \%$ are Admin \& Human Capital department, $8 \%$ are from ICT, 34\% are from other departments. We also have respondents from Legal dept, Finance and account (2\%).

Table 4.5 What is your highest level of Education?

\begin{tabular}{|c|c|c|c|c|c|}
\hline & & Frequency & Percentage & $\begin{array}{l}\text { Valid } \\
\text { Percentage }\end{array}$ & $\begin{array}{l}\text { Cumulative } \\
\text { Percentage }\end{array}$ \\
\hline \multirow[t]{4}{*}{ Valid } & Certificate/diploma & 1 & 2.0 & 2.0 & 2.0 \\
\hline & $\begin{array}{l}\text { Bachelor degree/Advance } \\
\text { diploma }\end{array}$ & 32 & 64.0 & 64.0 & 66.0 \\
\hline & Masters degree and Ph.D. & 17 & 34.0 & 34.0 & 100.0 \\
\hline & Total & 50 & 100.0 & 100.0 & \\
\hline
\end{tabular}

The table above shows the educational qualifications of the respondents surveyed.

The table (4.5) indicates the educational qualification of the respondents, Bulk of the respondents hold Bachelor degree/Advance diploma (64\%) while 34\% are holders of Masters and Ph.D

Table 4.6 What is your gender/

\begin{tabular}{|ll|l|l|l|l|}
\hline & Frequency & Percentage & Valid Percentage & Cumulative Percentage \\
\hline Valid & Male & 30 & 60.0 & 60.0 & 60.0 \\
& Female & 20 & 40.0 & 40.0 & 100.0 \\
& Total & 50 & 100.0 & 100.0 & \\
\hline
\end{tabular}

The table above shows the gender of the respondents

Table 4.6 shows the gender of the respondents, while $60 \%$ of them are male, the remaining $40 \%$ are females.

Usage of E-procurement 
First, respondents were asked whether their Organization uses E-procurement or not. Result from table 4.7 below shows that $62 \%$ (equivalent 31 people) confirmed that their organization use E-procurement while $36 \%$ (equivalent to 18 people) mentioned that their Organization was not using E-procurement. It was onlya respondent that was not sure whether his organization uses E-procurement or not.

Table 4.7 Does your Organization use electronic procurement?

\begin{tabular}{|ll|l|l|l|l|}
\hline & Frequency & Percentage & Valid Percentage & Cumulative Percentage \\
\hline Valid & Yes & 31 & 62.0 & 62.0 & 62.0 \\
& No & 36.0 & 36.0 & 98.0 \\
& DON'T KNOW & 1 & 2.0 & 2.0 & 100.0 \\
Total & 50 & 100.0 & 100.0 & \\
\hline
\end{tabular}

\section{COMPATIBILITY CHARACTERISTICS}

Table 4.8 Is using E-procurement very suitable with the way your Organization does business?

\begin{tabular}{|c|c|c|c|c|c|}
\hline & & Frequency & Percentage & $\begin{array}{l}\text { Valid } \\
\text { Percentage }\end{array}$ & $\begin{array}{l}\text { Cumulative } \\
\text { Percentage }\end{array}$ \\
\hline \multirow[t]{6}{*}{ Valid } & Strongly Agree & 16 & 32.0 & 32.0 & 32.0 \\
\hline & Agree & 23 & 46.0 & 46.0 & 78.0 \\
\hline & Neither Agree nor disagree & 6 & 12.0 & 12.0 & 90.0 \\
\hline & Disagree & 2 & 4.0 & 4.0 & 94.0 \\
\hline & Strogly disagree & 3 & 6.0 & 6.0 & 100.0 \\
\hline & Total & 50 & 100.0 & 100.0 & \\
\hline
\end{tabular}

We examined how E-procurement fits well with the way respondents' organizations does business. From table 4.8, out of 50 respondents; $32 \%$ 'strongly agreed' that, using e-procurement fits well with the way their organizations do business while $46 \%$ respondents 'agreed', $12 \%$ 'neither agree nor disagree' while $4 \%$ and $6 \%$ 'disagreed' and 'strongly disagreed' respectively (refer to table 4.8).

The result was very similar to how E-procurement is very suitable with the way these organizations do business with their partners (suppliers). Examining the compatibility of E-procurement with the organization's IT platform, 28\% strongly agreed that using E-procurement fits well with their existing IT system, 54\% only agreed, $10 \%$ neither agreed nor disagreed while 4\% disagreed with the above statement. (see table 4.9 below).

Table 4.9 Is using E-procurement very suitable with the way your Organization does business with your Partners?

\begin{tabular}{|c|c|c|c|c|c|}
\hline & & Frequency & Percentage & \begin{tabular}{|l} 
Valid \\
Percentage
\end{tabular} & $\begin{array}{l}\text { Cumulative } \\
\text { Percentage }\end{array}$ \\
\hline $\begin{array}{l}\text { Valid } \\
\\
\text { Missing } \\
\text { Total }\end{array}$ & $\begin{array}{l}\text { Strongly Agree } \\
\text { Agree } \\
\text { Neither Agree nor } \\
\text { disagree } \\
\text { Disagree } \\
\text { Strogly disagree } \\
\text { Total } \\
\text { System }\end{array}$ & $\begin{array}{l}17 \\
22 \\
6 \\
2 \\
2 \\
49 \\
1 \\
50\end{array}$ & $\begin{array}{l}34.0 \\
44.0 \\
12.0 \\
4.0 \\
4.0 \\
98.0 \\
2.0 \\
100.0\end{array}$ & $\begin{array}{l}34.7 \\
44.9 \\
12.2 \\
4.1 \\
4.1 \\
100.0\end{array}$ & $\begin{array}{l}34.7 \\
79.6 \\
91.8 \\
95.9 \\
100.0\end{array}$ \\
\hline
\end{tabular}

Table 4.9

The table shows how suitable is e-procurement to how their partners do business in the various organization. 


\section{Complexity characteristics}

These variables were trying to look at the flexibility of E-procurement with the employees, business partners as well as the existing IT platforms in the different organizations.

Table 4.10 Do you agree that using E-procurement is easy for the employees?

\begin{tabular}{|ll|l|l|l|l|}
\hline & & & Valid & Cumulative \\
& Frequency & Percentage & Percentage & Percentage \\
\hline Valid & Strongly Agree & 9 & 18.0 & 18.0 & 18.0 \\
& Agree & 23 & 46.0 & 46.0 & 64.0 \\
& Neither Agree nor disagree & 14 & 28.0 & 28.0 & 92.0 \\
Disagree & 4 & 8.0 & 8.0 & 100.0 \\
Total & 50 & 100.0 & 100.0 & \\
\hline
\end{tabular}

Table 4.10 shows that 50 respondents that completed the questionnaires showed that $18 \%$ and $46 \%$ strongly agree and agreed respectivelythat E-procurement is easy to use for their employees. $28 \%$ neither agreed nor disagreed while $8 \%$ disagreed with the statement.

Table 4.11 Do you agree using E-procurement is explicit to your business partners?

\begin{tabular}{|ll|l|l|l|l|}
\hline & & & Valid & Cumulative \\
& Frequency & Percentage & Percentage & Percentage \\
\hline Valid & Strongly Agree & 7 & 14.0 & 14.0 & 14.0 \\
& Agree & 24 & 48.0 & 48.0 & 62.0 \\
Neither Agree nor disagree & 16 & 32.0 & 32.0 & 94.0 \\
Disagree & 3 & 6.0 & 6.0 & 100.0 \\
Total & 50 & 100.0 & 100.0 & \\
\hline
\end{tabular}

Table 4.11

The table above shows if e-procurement is explicit to the organizations business partners.

Table 4.11 examined if E-procurement concept is explicit to their respective business partners, $14 \%$ and $48 \%$ strongly agreed and agreed respectively that E-procurement concept is clear and understandable to their business partners, $32 \%$ neither agreed nor disagreed while $6 \%$ disagreed with the statement.

Table 4.12 below shows that $16 \%$ and $60 \%$ strongly agreed and agreed respectively that "learning how to use additional e-procurement technology services" is easy for their employees, $20 \%$ neither agree or disagree while $4 \%$ ( 2 people) completely disagreed with the statement (See table 4.12 below).

Table 4.12 Do you agree that learning how to use additional E-procurement technology services is easy for the employees

\begin{tabular}{|l|l|l|l|l|}
\hline & Frequency & Percentage & Valid Percentage & Cumulative Percentage \\
\hline Valid Strongly Agree & 8 & 16.0 & 16.0 & 16.0 \\
Agree & 30 & 60.0 & 60.0 & 76.0 \\
Neither Agree nor disagree & 10 & 20.0 & 20.0 & 96.0 \\
Strongly disagree & 2 & 4.0 & 4.0 & 100.0 \\
Total & 50 & 100.0 & 100.0 & \\
\hline
\end{tabular}

Table 4.12

The above table shows if the use of additional e-procurement is easy for the employees.

Technology infrastructure characteristics

This is the section that evaluated Computer availability, connection to the National Fibre Optics and sufficiency of existing infrastructures that will enhance the use of E-procurement.

Table 4.13 Does using E-procurement fits well with existing Information system?

\begin{tabular}{|ll|l|l|l|l|}
\hline & Frequency & Percentage & Valid Percentage & Cumulative Percentage \\
\hline Valid & Strongly Agree & 14 & 28.0 & 28.0 & 28.0 \\
& 27 & 54.0 & 54.0 & 82.0 \\
Agree & 5 & 10.0 & 10.0 & 92.0 \\
Neither Agree nor disagree & 2 & 4.0 & 4.0 & 96.0 \\
Disagree & 2 & 4.0 & 4.0 & 100.0 \\
Strongly disagree & 50 & 100.0 & 100.0 & \\
Total & \multicolumn{3}{|l}{} \\
\hline
\end{tabular}


Table 4.13 above shows that $51.6 \%$ (26 people) confirmed that their organizations have connected to the National Fibre Optic for easy use of E-procurement, 29\% (9 people) were not sure while 19.3\% (6 people) said that their organizations have not connected to National Fibre Optic.

Table 4.14 evaluated whether E-procurement fits well with the existing IT system, while $28 \%$ strongly agreed, $58 \%$ agreed, $10 \%$ neither agree nor disagree, $4 \%$ disagreed and the remaining $4 \%$ strongly disagreed.

The table above shows if the existing information system fits well with e-procurement.

\section{Perceived benefits characteristics}

These are enquiries to examine the benefits of adoption of E-procurement in comparison to Cost. Respondents were asked if adoption of E-procurement has reduced their firm's transaction cost by $\mathbf{5 0 \%}$ ? Table 4.14 below indicated that only 12\% respondents strongly agreed with this statement, $24 \%$ agreed, $38 \%$ neither agree nor disagree, $18 \%$ disagreed with the statement.

As regards improvement in data accuracy through adoption of E-procurement, 24\% respondents strongly agreed, $42 \%$ agreed, $24 \%$ neither agree nor disagree while $2 \%$ disagreed.

$18 \%$ strongly believed that adopting E-procurement has increased the installation and administrative costs, $38 \%$ neither agree nor disagree while $10 \%$ disagreed that installation and other administrative costs have increased through E-procurement adoption.

Table 4.14 Do you agree that adoption of E-procurement has reduced your firm's transaction cost by $50 \%$ ?

\begin{tabular}{|ll|l|l|l|l|}
\hline & & Frequency & Percentage & $\begin{array}{l}\text { Valid } \\
\text { Percentage }\end{array}$ & $\begin{array}{l}\text { Cumulative } \\
\text { Percentage }\end{array}$ \\
\hline Valid & Strongly Agree & 6 & 12.0 & 13.0 & 13.0 \\
& Agree & 12 & 24.0 & 26.1 & 39.1 \\
& Neither Agree nor disagree & 19 & 38.0 & 41.3 & 80.4 \\
& Disagree & 7 & 14.0 & 15.2 & 95.7 \\
& Strongly disagree & 2 & 4.0 & 4.3 & 100.0 \\
Missing & Total & 46 & 92.0 & 100.0 & \\
Total & System & 4 & 8.0 & & \\
\hline
\end{tabular}

Table 4.14

The table above shows that adoption of e-procurement has reduced firm's transaction cost by $50 \%$.

User involvement characteristics

The study attempted to gauge the buy-in of the employees in their various organizations.22\% respondents strongly agreed, 40\% agreed that E-procurement adoption has enabled their organizations to involve most of their employees in the procurement process, $32 \%$ neither agree nor disagree while $4 \%$ completely disagreed.

$14 \%$ respondents strongly agreed, $48 \%$ agreed that E-procurement adoption has enabled employee effective participation in the procurement method to involve most of their employees in the procurement process, $26 \%$ neither agree nor disagree while $8 \%$ completely disagreed, $4 \%$ did not respond.

\section{Relative advantage characteristics}

Respondents were probed to evaluate the relationship of their business partners with their organizations, Efficiency and Effectiveness attributed to E-procurement adoption and whether there was value for money for this concept.

Significant percentage alluded to the enhancement of business partners relationship as $26 \%$ and $38 \%$ confirmed that E-procurement makes better their organization relationship with their business partners, $30 \%$ neither agree nor disagree, only $2 \%$ disagreed.

In a similar manner, $34 \%$ and $42 \%$ confirmed that E-procurement improves their efficiency and effectiveness, $16 \%$ neither agree nor disagree, only $6 \%$ disagreed.

$24 \%$ and 54\% confirmed that E-procurement will enable their organisations achieve value for money, 20\% neither agree nor disagree, nobody disagreed with the statement.

\section{Benefits characteristics of e-procurement}

Adopting E-procurement, it is expected that there should be reduction of paper work and errors which will translate to achieving more competitive bids, reducing ordering cost and cycle time. These parameters were equally examined.

Result showed that $44 \%$ respondents strongly agreed while $34 \%$ agreed that adoption of E-procurement led 
to reduction of paper work in their Organization, $14 \%$ neither agree nor disagree and only $4 \%$ completely disagreed. $4 \%$ did not respond at all.

Further, 24\% and 44\% respondents respectively strongly agreed and agreed that their Organization were better in compliance and error reduction, $18 \%$ neither agree nor disagree, $6 \%$ disagreed while $8 \%$ did not respond.

$63.6 \%$ agreed that E-procurement adopted achieved reduced ordering cost by higher percentage while $36.4 \%$ neither agree nor disagree.

Through the adoption of E-procurement, $16 \%$ respondents strongly agreed that their Organization achieved competitive bids, $42 \%$ also agreed with the statement while $32 \%$ neither agree nor disagree, only $10 \%$ did not respond.

The concept has also performed well in reducing the cycle time by more than $90 \%$ as we gathered that $22 \%$ of the respondents strongly agreed with the statement, $32 \%$ also agreed, $30 \%$ neither agreed nor disagree. $6 \%$ disagreed while $2 \%$ strongly disagreed, $8 \%$ did not respond.

\section{Regression analysis}

This is a method for investigating the functional relationships among variables, thus given the response variable $\mathrm{Y}$, and the set of predictor variables $X_{1}, X_{2}, X_{3}, \ldots X_{k}$ where k denotes the number of predictor variables. The true relationship between $\mathrm{Y}$ and $X_{1}, X_{2}, X_{3}, \ldots X_{k}$ can be approximated by regression.

The general form of multiple Linear Regression model is $Y_{t}=\beta_{1} X_{1 t}+\beta_{2} X_{2 t}+\cdots---+\beta_{k} X_{l t}+U_{t w h e r e ~}=1,2, \ldots \ldots \ldots \ldots . \mathrm{n}$,

Alternatively, $Y_{n}=\beta_{1} X_{n}$ | $\beta_{2} X_{n 2}$ । $\cdots \quad$ | $\beta_{k} X_{n k}$ । $U_{n}$

In vector form, $\mathrm{Y}=\mathrm{X} \beta+\varepsilon$

$\mathrm{Y}=$ Dependent variable

$\mathrm{X}=$ Explanatory variables

$\beta=$ Regression coefficients (a vector of $\mathrm{k} x \mathrm{1})$

$\varepsilon=$ Residual Error of $\mathrm{n} \times 1$ matrix

In this study, Value addition (VALAD) is considered to be the response variable while technological infrastructure (TINF), Organization Size (ORGSIZ) and Top Management Attitude (TMATT) are considered as predictor variables. Table 4.15 below shows the descriptive statistics of these variables.

The mean values of VALAD, TINF, ORGSIZ and TMATT are 2.0826, 2.3475, 2.0638 and 2.3759 respectively while the standard deviations are presented in the same table.

\section{Table 4.15 Descriptive Statistics}

\begin{tabular}{|l|l|l|l|}
\hline & Mean & Std. Deviation & N \\
\hline VALAD & 2.0826 & .69888 & 47 \\
\hline TINF & 2.3475 & .77150 & 47 \\
ORGSIZ & 2.0638 & .57162 & 47 \\
\hline TMATT & 2.3759 & .73431 & 47 \\
\hline
\end{tabular}

\section{Correlation coefficient}

This is a quantity that measures the direction and the strength of relationship between two variables $\mathrm{X}$ and Y. It takes value between -1 and +1 . Table 4.16 below shows pairwise correlation coefficient, the magnitude of the correlation between 'Value addition' and 'Technological Infrastructure' is 0.44 showing "fairly positive linear correlation", while it is 0.589 "moderate positive linear correlation" between 'Value addition' and 'Organization size'. The correlation between 'Value addition' and 'Top Management Attitude' is 0.652 (strong linear correlation). 


\begin{tabular}{|c|c|c|c|c|c|}
\hline & & VALAD & TINF & ORGSIZ & TMATT \\
\hline \multirow[t]{4}{*}{ Pearson Correlation } & VALAD & 1.000 & .440 & .589 & .652 \\
\hline & TINF & .440 & 1.000 & .620 & .557 \\
\hline & ORGSIZ & .589 & .620 & 1.000 & .632 \\
\hline & TMATT & .652 & .557 & .632 & 1.000 \\
\hline \multirow[t]{4}{*}{ Sig. (1-tailed) } & VALAD &. & .001 & .000 & .000 \\
\hline & TINF & .001 & . & .000 & .000 \\
\hline & ORGSIZ & .000 & .000 & & .000 \\
\hline & TMATT & .000 & .000 & .000 & . \\
\hline \multirow[t]{4}{*}{$\mathrm{N}$} & VALAD & 47 & 47 & 47 & 47 \\
\hline & TINF & 47 & 47 & 47 & 47 \\
\hline & ORGSIZ & 47 & 47 & 47 & 47 \\
\hline & TMATT & 47 & 47 & 47 & 47 \\
\hline
\end{tabular}

Table 4.17 Variables Entered/Removed ${ }^{\mathrm{a}}$

\begin{tabular}{|l|l|l|l|}
\hline Model & Variables Entered & Variables Removed & Method \\
\hline 1 & TMATT, TINF, ORGSIZ & . & Enter \\
\hline
\end{tabular}

Table 4.17 shows that Value addition is considered as dependent variable while three variables as explained earlier are independent variables.
a. Dependent Variable: VALAD
b. All requested variables entered.

4.18 Model Summary ${ }^{b}$

\begin{tabular}{|c|c|c|c|c|c|c|c|}
\hline \multirow[b]{2}{*}{ Model } & \multirow[b]{2}{*}{$\mathrm{R}$} & \multirow[b]{2}{*}{ R Square } & \multirow[b]{2}{*}{\begin{tabular}{|ll} 
Adjusted & $\mathrm{R}$ \\
Square &
\end{tabular}} & \multirow[b]{2}{*}{$\begin{array}{l}\text { Std. Error of the } \\
\text { Estimate }\end{array}$} & \multicolumn{3}{|l|}{ Change Statistics } \\
\hline & & & & & \begin{tabular}{|lr}
$\mathrm{R}$ & Square \\
Change & \\
\end{tabular} & F Change & df1 \\
\hline 1 & $.691^{\mathrm{a}}$ & .477 & .440 & .52282 & .477 & 13.066 & 3 \\
\hline
\end{tabular}

\section{Model Summary}

\begin{tabular}{|l|l|l|}
\hline \multirow{2}{*}{ Model } & \multicolumn{2}{|l|}{ Change Statistics } \\
\cline { 2 - 3 } & $\mathrm{df2}$ & Sig. F Change \\
\hline 1 & 43 & .000 \\
\hline
\end{tabular}

a. Predictors: (Constant), TMATT, TINF, ORGSIZ

b. Dependent Variable: VALAD

Table 4.18 is a model summary table that gives insight about the quality of the model fitted to the data. the correlation coefficient is 0.691 indicating a strong positive linear correlation between the 'Value addition' and the 'explanatory variables'.

R-square also known as coefficient of determinationand adjusted R-square measure the amount of variation in the dependent variable "Value addition" that was explained(accounted) for by the explanatory variables

(Technological infrastructure, Organization size and Top management attitude). $0 \leq R^{2} \leq 1$

Thus, from the table, $44 \%$ of the variation in "Value addition"was explained by the explanatory variables. This implies that the model is fairly effective in predicting the relationship between the dependent and independent variables.

The P-value is $0.000<0.05$ showing that the model is statistically significant. 
4.19 Anova $^{a}$

\begin{tabular}{|ll|l|l|l|l|l|}
\hline Model & Sum of Squares & df & Mean Square & F & Sig. \\
\hline 1 & Regression & 10.715 & 3 & 3.572 & 13.066 & $.000^{\mathrm{b}}$ \\
\cline { 2 - 7 } & Residual & 11.754 & 43 & .273 & & \\
& Total & 22.468 & 46 & & & \\
\end{tabular}

a. Dependent Variable: VALAD

b. Predictors: (Constant), TMATT, TINF, ORGSIZ

Table 4.19 shows the Analysis of variance of the model (ANOVA) for the multiple regression.Employing F-test, we can test the hypothesis that all the regression coefficients are not significant except the constant term.

The hypothesis is thus formulated:

$H_{0}: \beta=0$, i.e All the explanatory variables $\mathrm{X}$ (Technological Infrastructure, Organization Size and Top ManagementAttitude) have no influence on 'Value addition'.

$H_{1}: \beta \neq 0_{i}$ i.e All the regressors $\mathrm{X}$ (Technological Infrastructure, Organization Size and Top ManagementAttitude) have influence on 'Value addition'

At $\alpha=0.05$, We reject the null hypothesis, because $\mathrm{F}=$ statistic is significant. This implies that all the regressors contribute to the prediction of 'Value addition'

$\mathrm{MSR}=3.572, \mathrm{MSE}=0.273$, F-statistic $=13.066$

The F-test shows that all the regressors are significant. This implies that Technological Infrastructure, Organization Size and Top ManagementAttitude) have influence on 'Value addition'

4.20 Partial regression coefficients ${ }^{\mathrm{a}}$

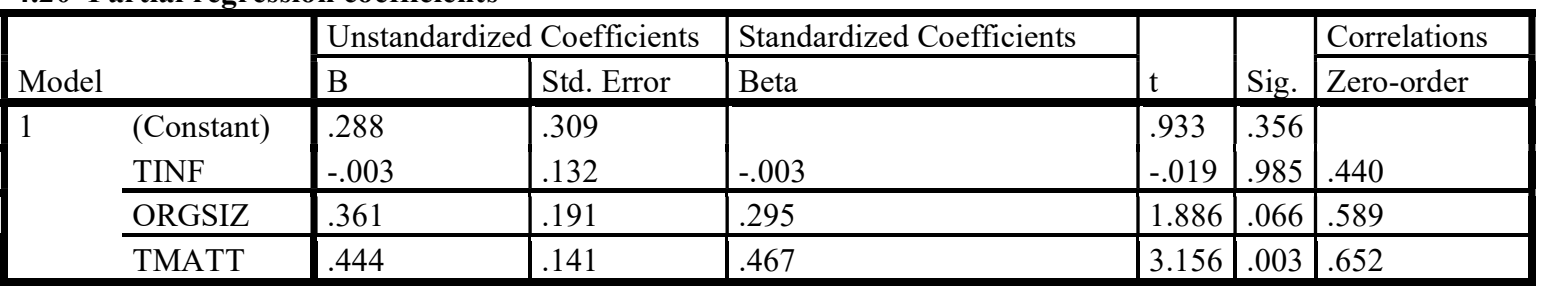

Table 4.20 represents the partial regression coefficients. This is interpreted change in the response variable corresponding to a unit change in the explanatory variable $\mathrm{X}$ when all other explanatory variables are held constant.

The constant and partial regression coefficients are $\hat{\beta}_{0}=0.288, \hat{\beta}_{1}=-0.003, \hat{\beta}_{2}=0.361, \hat{\beta}_{3}=0.444$

The fitted regression equation is $\widehat{Y}_{\text {valud }}$

\section{$=0.288-0.003$ Tinf $_{i}+0.361$ orgsiz $_{j}+0.444$ tmatt $_{k}$}

Interpretation

1. The constant coefficient is 0.288 , This represents the base or the background level of the response variable (Value addition)

2. Each unit of Technological infrastructureremoves 0.003 from the value addition when all other variables are fixed. An increase of $1 \%$ in Technological infrastructure led to 3 per cent decrease in Value addition.

3. Each unit of Organization size adds 0.361 to Value addition when other variables are fixed. An increase of $1 \%$ in Organization size led to 36.1 per cent increase in Value addition.

4. Each unit of Top Management Attitude adds 0.444 to Value addition when other variables are fixed. An increase of $1 \%$ Top Management Attitude led to 44.4 per cent increase in Value addition.

Inference for individual regression coefficients

The null hypotheses are specified as follows:

Ho1: Technological Infrastructure has no significant impact in the prediction of organization performance

Ho2: Organization size has no significant impact in the prediction of organization performance

Ho3: Top Management Attitude no significant impact in the prediction of organization performance.

The alternative hypotheses are as follows:

H11: Technological Infrastructure has impact in the prediction of organization performance

H12: Organization size has impact in the prediction of organization performance

H13: Top Management Attitude impact in the prediction of organization performance

From table 4.20 , t-statistic of $\left(\hat{\beta}_{0}\right)=0.933$, t-statistic of $\left(\hat{\beta}_{1}\right)=-0.019$, t-statistic of $\left(\hat{\beta}_{2}\right)=1.8886$, t-statistic of 
$\left(\tilde{\beta}_{3}\right)=3.156$

At $\alpha=0.05$, the significance of Top Management Attitude, Organization size and Technological Infrastructure are $0.003,0.066$ and 0.985 respectively. This impliesthat Top Management Attitude is the only statistically significant variable (value less than 0.05), while Technological Infrastructure and Organization size are not statistically significant. Hence, Top Management Attitude is the statistically significant predictor of Value addition after adjusting for Organization size and Technological Infrastructure.

\subsection{Conclusion}

The main objective was to evaluate the impact of E-procurement on the performance of Public Sector Organizations in Nigeria in particular INEC, TETFUND and NBS. This study was guided by the following straight Objectives: to ascertain the effectiveness of E-procurement in the Three MDAs, to evaluate the performance level of E-procurement in the MDAs and to find out the relationship between E-procurement and Performance in these specific MDAs. In order to achieve the above objectives, Questionnaires were administered to a group of 50 Respondents who are staff of INEC, TETFUND and NBS.

As indicated above in the different tables, among all the results provided there were only some issues that respondents were undecided on or disagreed on and the rest were agreed and strongly agreed. Therefore Eprocurement activities are generally effective and aids smooth running of Organizations . Secondly Eprocurement has helped in reducing the cost of doing business in the three MDAs. In addition researcher learnt that INEC, TETFUND and NBS have all experienced an improvement in their performance since the introduction of E-procurement. By the findings E-procurement has strong impact on the performance of the three MDAs.

From the result of the regression analysis, TMATT with a $\mathrm{P}$ value of 0.003 is statistically significant while other explanatory variables are not.We reject Ho3 and we do not reject Ho1 and Ho2.It is concluded that Top management attitude has significant impact on Organization performance.

\subsection{Recommendations.}

The findings gotten from this study hold important implications for all stakeholders like government, public institutions, non-government owned institutions and suppliers. The government could use the findings of this study to understand and monitor the use and spread of E-procurement in other MDAs since E-procurement is of global relevance all over the world.

Continuous focus should be on improving information technology infrastructure which is necessary to fully implement E-procurement in all MDAs.On public awareness since E-procurement is a topical issue the Bureau of Public Procurement and the Federal Government is recommended to keep sensitizing the general public on the importance of E-procurement. And embark on trainings on how to use the all encompassing software to be introduced even before it arrives into the country.

\subsection{Areas of further research}

Further researches are suggested to increase on the sample size and techniques in order to obtain a more representative of the population. E-procurement is a multi-dimensional concept; further research can consider the use of other E-procurement functions like E-sourcing, E-tendering, E-payment, E-transportation E-evaluation and E-negotiation. A larger number of questionnaire can be given out to staff of more Public sector organizations in Nigeria to get a more reliable analysis on the research.

\section{References}

[1] Aduwo, E., Ibem, E., Afolabi, A., Oluwunmi, A., Tunji-Olayeni, P., Ayo-Vaughan, E.,\& Oni, A. (2020). Exploring anti-corruption capabilities of e-procurement in construction project delivery in Nigeria. Construction Economics and Building, 20(1).

[2] Akaba, T. I., Norta, A., Udokwu, C., \&Draheim, D. (2020, April). A framework for the adoption of blockchain-Based e-Procurement systems in the public sector.In Conference on e-Business, e-Services and e-Society (pp. 3-14).

[3] Bosco,H. J.(2018). The Impact of E-Procurement on the Performance of Public Institutions in Rwanda. Global Journal of Management And Business Research, [S.1.], 24

[4] Carayannis, E. G., \&Popescu, D. (2005). Profiling a methodology for economic growth and convergence: learning from the EU e-procurement experience for central and eastern European countries. Technovation, 25(1), 1-14.

[5] Cooper and Schindler. (2003).Researchmethodology, $2^{\text {nd }}$ edition, New York: Pinkwell Publishers.

[6] Gihozo, D. (2020). Adoption of e-procurement in Rwandan Public institutions.

[7] Ibem, E. O., Aduwo, E. B., Afolabi, A. O., Oluwunmi, A. O., Tunji-Olayeni, P. F., Ayo-Vaughan, E. A., 
\&Uwakonye, U. O. (2020). Electronic (e-) Procurement Adoption and Users' Experience in the Nigerian Construction Sector. International Journal of Construction Education and Research, 1-19.

[8] Matunga, D. A., Nyanamba, S. O., \&Okibo, W. (2013). The effect of e-procurement practices on effective procurement in public hospitals: A case of Kisii level 5 hospital. American International Journal of Contemporary Research, 3(8), 103-111.

[9] Procurement procedures manual of the Bureau of Public Procurement Nigeria.

[10] Public Procurement Act,2007 of the Bureau of Public Procurement Nigeria.

[11] Public procurement goods and works regulations 2007 Nigeria.

[12] Roman, A. V. (2013). Public policy and financial management through eprocurement: A practice oriented normative model for maximizing transformative impacts. Journal of public procurement. 13(03) 337-363

[13] Samaniego, M. J. G., Arranz, A. M. G., \&Cabezudo, R. S. J. (2006). Determinants of internet use in the purchasing process. Journal of Business \& Industrial Marketing.

[14] Schoenherr, T. (2019). The evolution of electronic procurement.In The Evolution of Electronic Procurement (pp. 33-46). Palgrave Pivot, Cham.

[15] Shatta, D. N., Shayo, F. A., \&Layaa, J. N. (2020). Determinants of e-procurement adoption model for green procurement in developing countries: Experience from Tanzania. International Academic Journal of Procurement and Supply Chain Management, 3(2), 1-18.

[16] Sherry, L., \& Gibson, D. (2002). The path to teacher leadership in educational technology. Contemporary issues in technology and teacher education, 2(2), 178-203. 